\title{
ANALISIS PENCAHAYAAN PENERANGAN JALAN UMUM DI JALAN TOL KABUPATEN PANGANDARAN DAN PELUANG HEMAT ENERGI
}

\author{
Rudini ${ }^{1}$, Edvin Priatna ${ }^{2}$, Ifkar Usrah ${ }^{3}$
}

Program Studi Teknik Elektro, Fakultas Teknik, Universitas Siliwangi 1,2,3

email:157002117@student.unsil.ac.id ${ }^{1}$

\begin{abstract}
Several problems regarding public street lighting are often found and do not comply with SNI standards. Among the things that are often found are the distance between PJU poles is not the same, the height of the PJU poles is not according to the standard, the installation of PJU is not well organized, the selection of lamp types and lamp power is not according to SNI standards, the lack of PJUs on roads that are crowded with vehicles resulting in less efficient when operating and the lack of comfort for road users due to the lack of light intensity at the PJU location due to several factors. To solve this problem, it is necessary to have a solution to solve existing problems, including by saving energy in public street lighting (PJU). Some things that need to be done are the replacement of street lights (PJU) that do not comply with standards, as well as an evaluation by the relevant agencies and agencies after the installation is complete. The condition of the existing PJU on the Pangandaran Regency Toll Road, the average illumination level produced by the SON-T $150 \mathrm{~W}$ lamp is 3.1 lux with an even lightness of 0.0. then it is not in accordance with SNI7391: 2008. The simulation results that have been carried out with Dialux 4.13 software, the average illumination level produced from the Philips LED $150 \mathrm{~W}$ luminaire is 11 lux with an even lightness of 0.106 lux. then it is in accordance with SNI 7391: 2008. For the simulation results of the Philips LED 120 W luminaire, the average illumination level is 11 lux with an even lightness of 0.114 lux. then the average illumination level and evenness value are in accordance with SNI 7391: 2008. From the simulation results that have been carried out with the Dialux 4.13 software, the use of $120 \mathrm{~W}$ LED lights on Public Street Lighting on the Pangandaran Regency Toll Road results in a $20 \%$ chance of saving electrical energy. .
\end{abstract}

Keywords: Public Street Lighting, Energy Saving, Analysis of Public Street Lighting.

\section{Abstrak}

Beberapa permasalahan tentang penerangan jalan umum kerap kali ditemukan dan tidak sesuai standar SNI. Di antaranya yang kerap ditemukan adalah jarak antar tiang PJU tidak sama, tinggi tiang PJU tidak sesuai standar, instalasi PJU yang kurang tertata, pemilihan jenis lampu serta daya lampu yang tidak sesuai standart SNI, kurangnya PJU di jalan yang padat kendaraan sehingga mengakibatkan kurang efisien pada saat beroperasi dan kurangnya kenyamanan pengguna jalan karena instensitas cahaya pada lokasi PJU yang kurang karena beberapa factor. Untuk mengatasi masalah tersebut, maka perlu adanya solusi untuk memecahkan permasalahan yang ada diantaranya dengan cara penghematan energi pada lampu penerangan jalan umum (PJU). Beberapa hal yang perlu dilakukan adalah pergantian lampu penerangan jalan umum (PJU) yang tidak sesuai standar, serta adanya evaluasi oleh badan dan instansi terkait setelah selesai pengerjaan pemasangan. Kondisi PJU eksisting di ruas Jalan Tol Kabupaten Pangandaran tingkat iluminasi rata-rata yang dihasilkan dari lampu SON-T 150W sebesar 3,1 lux dengan kemerataan cahaya sebesar 0,0. maka belum sesuai SNI7391:2008. Hasil simulasi yang telah dilakukan dengan sofware dialux 4.13, tingkat iluminasi rata-rata yang dihasilkan dari luminer Philips LED $150 \mathrm{~W}$ sebesar 11 lux dengan kemerataan cahaya sebesar 0.106 lux. maka sudah sesuai SNI 7391:2008. Untuk hasil simulasi dari luminer Philips LED $120 \mathrm{~W}$ tingkat iluminasi rata-rata sebesar 11 lux dengan kemerataan cahaya sebesar 0.114 lux. maka tingkat iluminasi rata-rata dan nilai kemerataan sudah sesuai SNI 7391:2008. Dari hasil simulasi yang telah dilakukan dengan sofware Dialux 4.13, penggunaan lampu LED $120 \mathrm{~W}$ pada Penerangan Jalan Umum dijalan Tol Kabupaten Pangandaran menghasilkan peluang penghematan energi listrik sebesar $20 \%$

Kata Kunci: Penerangan Jalan Umum, Penghematan Energi, Analisis Pencahyaan Penerangan Jalan Umum.

\section{Pendahuluan}

Jalan Tol Kabupaten Pangandaran merupakan jalan masuk kedaerah wisata Pantai Pangandaran. Dengan banyaknya jumlah wisatawan yang terdapat di Pantai Pangandaran dan juga aktivitas wisatawan dimalam hari, maka dibutuhkan lampu penerangan jalan (PJU) guna menunjang keselamatan dan keamanan para wisatawan yang berkunjung ke Pantai Pangandaran[1]

Penerangan jalan umum (PJU) dijalan Tol Kabupaten Pangandaran berjumlah 18 tiang dengan tinggi 7 meter dan jarak antar tiang tiang berjarak 50 meter dan menggunakan lampu Son T 150 Watt, dengan jumlah 33 lampu masih menyala dengan baik dan 3 lampu padam. Serta masuk dalam klasifikasi jalan arteri primer dan menurut SNI 7391:2008 Tentang Spesifikasi penerangan jalan dikawasan perkotaan kuat cahaya (E) rata rata 11-20 Lux. Dan kemeratan cahaya $0,14-0,20$ Lux.

Pencahayaan jalan umum atau sering disebut sebagai Penerangan Jalan Umum (PJU) merupakan aspek penting dalam penataan suatu daerah/kota. PJU memiliki peranan sebagai pedoman navigasi pengguna jalan di malam hari, meningkatkan keamanan dan keselamatan pengguna jalan, menambah unsur estetika, dan juga dapat memberikan nilai tambah ekonomi bagi suatu daerah. Namun sayangnya banyak Pemerintah Daerah yang masih mengalami kendala dalam menyediakan fasilitas publik yang sangat penting ini terutama dalam hal perencanaan sistem PJU yang efisien energi.

Tidak sedikit Pemerintah Daerah mengalami kesulitan dalam pembiayaan untuk pengelolaan operasional PJU yang dimilikinya dikarenakan tingginya 
biaya energi yang harus dibayarkan kepada perusahaan penyedia tenaga listrik PJU, PT PLN (Persero), apa lagi untuk ekspansi pembangunan PJU yang baru. Kondisi ini menyebabkan masyarakat tidak dapat menikmati layanan pencahayaan dijalan umum pada malam hari dengan optimal, karenanya efisiensi energi PJU adalah keharusan[2]

Kabupaten Pangandaran terbentuk berdasarkan Undang-Undang Nomor 21 Tahun 2012 tentang Pembentukan Kabupaten Pangandaran di Provinsi Jawa Barat. Dalam UU tersebut disebutkan bahwa Kabupaten Pangandaran berasal dari sebagian wilayah Kabupaten Ciamis, yang terdiri dari : Kecamatan Parigi, Kecamatan Cijulang, Kecamatan Cimerak, Kecamatan Cigugur, Kecamatan Langkaplancar, Kecamatan Mangunjaya, Kecamatan Padaherang, Kecamatan Kalipucang, Kecamatan Pangandaran dan Kecamatan Sidamulih. Ibu Kota Kabupaten Pangandaran berkedudukan di Kecamatan Parigi.

Dengan potensi yang besar dibidang pariwisata maka misi Kabupaten Pangandaran yaitu "Kabupaten Pangandaran Pada tahun 2025 menjadi kabupaten pariwisata yang berkelas dunia, tempat tinggal yang aman dan nyaman berlandaskan norma agama[3]

Beberapa permasalahan tentang penerangan jalan umum kerap kali ditemukan dan tidak sesuai standar SNI. Di antaranya yang kerap ditemukan adalah jarak antar tiang PJU tidak sama, tinggi tiang PJU tidak sesuai standar, instalasi PJU yang kurang tertata, pemilihan jenis lampu serta daya lampu yang tidak sesuai standart SNI, kurangnya PJU di jalan yang padat kendaraan sehingga mengakibatkan kurang efisien pada saat beroperasi dan kurangnya kenyamanan pengguna jalan karena instensitas cahaya pada lokasi PJU yang kurang karena beberapa faktor. Mengurangi tingkat pencahayaan dengan mematikan, pencahayaan sebagian malam, atau peredupan dapat mengurangi jarak pandang suatu area, yang dapat meningkatkan resiko kecelakaan jika pengguna jalan tidak lagi dapat mendeteksi bahaya[4]

Penerangan Jalan Umum (PJU) harus memenuhi standar pencahayaan yang dipersyaratkan serta efisien dalam penggunaan energinya. Dalam tulisan ini dilakukan analisis terhadap PJU di ruas Jalan Pesisir Pantai Barat Pangandaran untuk dapat mengetahui penyebaran kuat pencahayaan dan konsumsi energi yang dipakai. Kondisi PJU di ruas Jalan Pesisir Pantai Barat Pangandaran masih belum sesuai standar pencahayaan SNI 7391:2008 untuk tipe jalan lokal dengan tingkat iluminasi rata-rata yang dihasilkan dari luminer PJU tersebut sebesar 4,9 lux, kemerataan cahaya (g1) sebesar 0,13 lux, dan konsumsi daya listrik sebesar 2.639,5 $\mathrm{kWh} /$ bulan dengan biaya listrik sebesar Rp. 3.872.885/bulan[5]

Berdasarkan uraian diatas maka penelitian ini membahas tentang Analisis pencahayaan penerangan jalan umum (PJU) dan peluang hemat energi. Sebagai objek penelitian diambil studi kasus di Jl. Tol Kabupaten Pangandaran.

\section{LANDASAN TEORI}

\section{A. Lampu Penerangan Jalan}

Lampu penerangan jalan adalah bagian dari bangunan pelengkap jalan yang dapat diletakkan/dipasang di kiri/kanan jalan dan atau di tengah (di bagian median jalan) yang digunakan untuk menerangi jalan maupun lingkungan di sekitar jalan yang diperlukan termasuk persimpangan jalan (intersection), jalan layang (interchange, overpass, fly over), jembatan dan jalan di bawah tanah (underpass, terowongan).

Lampu penerangan yang dimaksud adalah suatu unit lengkap yang terdiri dari sumber cahaya (lampu/luminer), elemen-elemen optik (pemantul/reflector, pembias/refractor, penyebar/diffuser). Elemen-elemen elektrik (konektor ke sumber tenaga/power supply. dll.), struktur penopang yang terdiri dari lengan penopang, tiang penopang vertikal dan pondasi tiang lampu [6].

\section{B. Fungsi penerangan jalan}

Penerangan jalan di kawasan perkotaan mempunyai fungsi antara lain:

1. Menghasilkan kekontrasan antara obyek dan permukaan jalan;

2. Sebagai alat bantu navigasi pengguna jalan;

3. Meningkatkan keselamatan dan kenyamanan pengguna jalan, khususnya pada malam hari;

4. Mendukung keamanan lingkungan;

5. Memberikan keindahan lingkungan jalan [7].

\section{Jenis Lampu Penerangan Jalan}

Jenis lampu penerangan jalan ditinjau dari karakteristik dan penggunaannya secara umum dapat dilihat dalam Tabel 1.

Tbl 1. Jenis Lampu Penerangan Jalan Secara Umum Menurut Karakteristik dan Penggunaannya

\begin{tabular}{|c|c|c|c|c|c|}
\hline $\begin{array}{c}\text { Jenis } \\
\text { Lampu }\end{array}$ & $\begin{array}{c}\text { Efisiensi } \\
\text { rata-rata } \\
\text { (lumen/wa) }\end{array}$ & $\begin{array}{l}\text { Umur } \\
\text { rencana } \\
\text { rata-rata } \\
\text { (jam) }\end{array}$ & $\begin{array}{l}\text { Daya } \\
\text { (watt) }\end{array}$ & $\begin{array}{c}\text { Pengaruh } \\
\text { thd } \\
\text { warna } \\
\text { obyek }\end{array}$ & Keterangan \\
\hline $\begin{array}{l}\text { Lampu } \\
\text { tabung } \\
\text { fluorescent } \\
\text { tekanan } \\
\text { rendah }\end{array}$ & $60-70$ & $\begin{array}{l}8.000- \\
10.000\end{array}$ & $\begin{array}{l}18-20 \\
36-40\end{array}$ & Sedang & $\begin{array}{l}\text { 1.Untuk jalan kolekt or dan lokal. } \\
\text { 2.Efisiensi cukup tinggi tetapi ber umur pendek. } \\
\text { 3. jenis lampu ini masih dapat diguna kan untuk } \\
\text { hal-hal yang terbatas. }\end{array}$ \\
\hline $\begin{array}{l}\text { Lampu gas } \\
\text { merkuri } \\
\text { tekanan } \\
\text { tinggi } \\
(\mathrm{MBF} / \mathrm{U}\end{array}$ & $50-55$ & $\begin{array}{l}16.000- \\
24.000\end{array}$ & $\begin{array}{l}125 ; 250 \\
400 ; 700\end{array}$ & Sedang & $\begin{array}{l}\text { 1.Untuk jalan kolek-tor, lokal dan persi- } \\
\text { mpangan. } \\
\text { 2.Efisiensi rendah, umur panjang dan ukuran } \\
\text { lampu kecil. }\end{array}$ \\
\hline
\end{tabular}


3.jenis lampu ini ma sih dapat digunak- an secara terbatas.

Lampu gas $100-200 \quad 8.000-\quad 90 ; 180 \quad$ Sangat $\quad$ 1.untuk jalan kolekt- or lokal, persimpa- ngan
sodium $10.000 \quad$ buruk penyeberang- ngan,teroowongan, tempat bertekanan peristiraha- tan rest area.

rendah

2.efisiensi sangat tin ggi, umur cukup panjang, (SOX) ukuran la- mpu besar sehing ga sulit untuk men gontrol cahayanya dan cahaya lampu sangat buruk kare -na warna kuning.

3.Jenis lampu ini dianjurkan digu nakan karena faktor effisiensi nya yang sangat tinggi.

$\begin{array}{lllll}\begin{array}{l}\text { Lampu gas } \\ \text { Sodium } \\ \text { tekanan }\end{array} & 110 & 12.000-150 ; 250 ; \text { Buruk } & \begin{array}{l}\text { 1.Untuk jalan tol,art eri, kolektor, persi- } \\ \text { mpangan besar / luas dan intercha-nge; }\end{array} \\ \begin{array}{l}\text { tinggi } \\ \text { (SON }\end{array} & 20.000 & 400 & & \begin{array}{l}\text { 2.Efisiensi tinggi,um ur sangat panjang, ukuran } \\ \text { lampu kecil sehingga mudah pe gontrolan } \\ \text { cahaya nya }\end{array}\end{array}$

Sumber: [7]

\section{1) Lampu LED}

Lampu LED merupakan lampu terbaru yang merupakan sumber cahaya yang efisien energinya. Ketika lampu LED memancarkan cahaya nampak pada gelombang spektrum yang sangat sempit, mereka dapat memproduksi "cahaya putih". Hal ini sesuai dengan kesatuan susunan merah-biru hijau atau lampu LED biru berlapis fospor. Lampu LED bertahan dari 40.000 hingga 100.000 jam tergantung pada warna. Lampu LED digunakan untuk banyak penerapan pencahayaan seperti tanda keluar, sinyal lalu lintas, cahaya dibawah lemari, dan berbagai penerapan dekoratif. Walaupun masih dalam masa perkembangan teknologi lampu LED sangat cepat mengalami kemajuan dan menjanjikan untuk masa depan. Berbagai perkiraan potensi penghematan energi berkisar dari $82 \%$ hingga 93\%. Produk pengganti LED, diproduksi dalam berbagai bentuk termasuk batang ringan, panel dan sekrup dalam lampu LED, biasanya memiliki kekuatan 2-5W masing-masing, memberikan penghematan yang cukup berarti dibanding lampu pijar[8]

\section{Formulasi Penerangan}

\section{1) Fluks Cahaya}

Fluks cahaya yang dipancarkan oleh suatu sumber cahaya adalah seluruh jumlah cahaya yang dapat dipancarkan oleh sumber cahaya selama satu detik. Jika sumber cahaya ditempatkan dalam suatu reflektor, maka cahaya yang dipancarkan akan diarahkøan tetapi jumlah fluks cahayanya tetap,dalam perhitungannya dapat ditulis dalam persamaan :

$$
\phi=\frac{Q}{t}
$$

dimana:

$\boldsymbol{\phi}=$ Fluks cahaya dalam lumen ( $1 \mathrm{~m})$

$\mathrm{Q}=$ Energi cahaya dalam lumen jam atau lumen detik

$\mathrm{t}=$ waktu dalam jam atau detik [9]

\section{2) Intensitas Cahaya}

Adalah arus cahaya yang dipancarkan oleh sumber cahaya dalam satu cone atau kerucut cahaya. Intensitas cahaya dapat diartikan fluks cahaya persatuan sudut ruang dalam arah pancaran cahaya yang ditulis dengan persamaan (2):

$$
I=\frac{\phi}{\omega}
$$

$\boldsymbol{\phi}=$ fluks cahaya, dalam satuan lumen ( $\mathrm{lm})$

$\mathrm{I}=$ intensitas cahaya, dalam satuan candela (cd)

$\omega=$ sudut ruang, dalam satuan steridian (sr)

\section{3) Iluminasi}

Iluminasi atau tingkat kuat cahaya penerangan didefinisikan sebagai sejumlah arus cahaya yang jatuh pada permukaan seluas 1 (satu) meter persegi sejauh 1 (satu) meter dari sumber cahaya 1 (satu) lumen dalam satuan Lux. Illuminasi dapat diartikan kerapatan fluks cahaya yang mengenai suatu permukaaan, intensitas penerangan rata-rata secara matematis dapat ditulis:

$$
E=\frac{\phi}{A}
$$

dengan:

$\mathrm{E}=$ illuminasi, dalam satuan lux (lx)

$\boldsymbol{\phi}=$ fluks cahaya, dalam satuan lumen (lm)

$\mathrm{A}=$ luas bidang, dalam satuan meter persegi (m2)

\section{4) Luminasi}

Luminasi adalah fluks cahaya per satuan sudut ruang per satuan luas terproyeksi dari arah yang diberikan, atau intensitas cahaya dari suatu permukaan persatuan luas hasil proyeksi dari arah yang diberikan. Luminasi ialah suatu ukuran terang suatu benda, luminasi yang terlalu besarakan menyilaukan mata. Besaran ini mempunyai persamaan (5):

$$
\begin{aligned}
L & =\frac{\phi}{\omega}(A x \cos \theta) \\
L & \left.=\frac{I}{A} x \cos \theta\right)
\end{aligned}
$$

dengan:

$\mathrm{L}=$ luminasi dalam satuan candela per meter persegi $(\mathrm{cd} / \mathrm{m} 2)$

$\theta=$ sudut antara penglihatan dengan bidang normal permukaan dalam satuan derajat (0)

$\boldsymbol{\phi}=$ fluks cahaya, dalam satuan lumen ( $\mathrm{lm})$

$\mathrm{A}=$ luas bidang, dalam satuan meter persegi (m2)[9] 


\section{5) Daya Lampu Total}

Ptotal $=P \times N$

Dimana:

$$
\begin{aligned}
& \mathrm{P}_{\text {total }}=\text { Daya lampu total }(\mathrm{W}) \\
& \mathrm{P}=\text { Daya lampu }(\mathrm{W}) \\
& \mathrm{N}=\text { Jumlah lampu }
\end{aligned}
$$

6) Daya Lampu Tiap Bulan

$$
\text { Ptotal }=P \times N
$$

Dimana: $\mathrm{P}_{\text {bulan }}=$ Daya lampu total tiap bulan

(kWh/bulan)

$\mathrm{P}_{\text {total }} \quad=$ Daya lampu total $(\mathrm{W})$

$\mathrm{t} \quad=$ Waktu nyala $(\mathrm{jam} / \mathrm{bulan})$

\section{METODE PENELITIAN}

\section{A. Flowchart Penelitian}

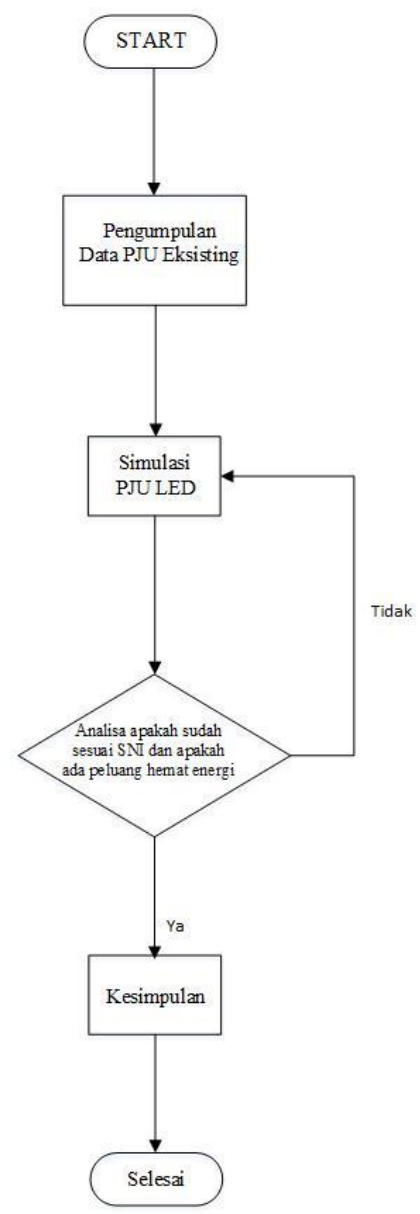

Gbr 1. Flowchart Penelitian

Pada gambar 1 menunjukan flowchart penelitian yang mana berguna sebagai langkah dalam menyelesaikan penelitian ini dimana urutannya sebagai berikut:

1. Mengumpulkan data yang dibutuhkan seperti jenis lampu apa saja yang dipakai PJU, berapa daya yang dipakai oleh lampu PJU, Jarak antar tiang PJU yang satu dengan yang lainya, dan tinggi tiang lampu PJU.

2. Selanjutnya melakukan pengukuran dengan Lux meter pada malam hari, pengukuran dilakukan dengan metode pengukuran 9 titik.
3. Selanjutnya melakukan simulasi lampu LED dengan sofware Dialux.4.13.

4. Kemudian dapat disimpulkan hasil dari pengukuran PJU ekssting dan simulasi PJU Led dengan sofware dialux 4.13. Apakah sudah sesuai dengan SNI atau tidak, serta apakah terdapat peluang hemat energi atau tidak.

B. Data Penerangan Jalan Umum (PJU) Di jalan Tol Kabupaten Pangandaran

Tbl 2. Data PJU Di Jalan Tol Kabupaten Pangandaran

\begin{tabular}{ccc}
\hline No & Data & Keterangan \\
\hline 1 & Jenis Lampu & SON-T \\
\hline 2 & Daya Lampu & 150 watt \\
\hline 3 & Lebar jalan kiri & 7 meter \\
\hline 4 & Lebar jalan kanan & 7 meter \\
\hline 5 & Lebar medin jalan & 5 meter \\
\hline 6 & Panjang jalan & 900 meter \\
\hline 7 & Jumah tiang & 18 tiang \\
\hline 8 & Jumlah lampu & 36 lampu \\
\hline 9 & Tinggi tiang & 7 meter \\
\hline 10 & Jarak antar tiang & 50 meter \\
\hline 11 & Lebar lengan tiang & 2 meter \\
\hline
\end{tabular}

Dari Tabel 2 data informasi yang didapat dari Dinas Perhubungan, jumlah tiang PJU sebanyak 18 tiang dengan 36 lampu, lampu yang masih menyala sebanyak 33 lampu dan 3 lampu dalam keadaan padam, dengan tinggi tiang 7 meter, jarak antar tiang 50 meter, dan menggunakan jenis lampu Son 150 Watt. Maka klasifikasi jalan Tol Kabupaten Pangandaran adalah jalan arteri primer.

Sehingga dapat disimpulkan bahwa kelas jalan sebagai studi kasus penelitian ini adalah jalan ateri bebas hambatan dan menurut SNI 7391:2008 kuat cahaya (E) rata rata 11-20 Lux. Dan kemeratan cahaya 0,14-0,20 Lux.

\section{Eksisting Penerangan Jalan Umum} (ans

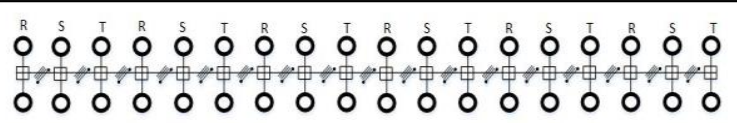

Gbr2. Single Line Penerangan Jalan Umum

Dari gambar 3.2 menunjukan bahwa Jalan Tol Kabupaten Panagandaran termasuk kelas jalan arteri dengan lebar jalan 5 meter, dengan panjang lokasi 900 meter. Jarak antar tiang PJU 50 meter, lampu Penerangan Jalan Umum di Jalan Tol Kabupaten Panagandaran berjumlah 18 tiang dengan jumlah lampu 36 lampu, dan lampu yang masih berfungsi dengan baik sebanyak 33 lampu, dan lampu yang tidak menyala sebanyak 3 lampu. Dengan tinggi tiang 7 meter, jaraka antar tiang 50 meter, dan menggunakan lampu Son T 150 Watt.

\section{Alat ukur penelitian}

\section{a) Lutron Light Meter LX $101 \mathrm{AS}$}

Agar proses penelitian ini memiliki hasil yang baik maka dibutukan alat sebagai pengukur kuat pencahayaan 
(iluminasi), alat ukur yang digunakan adalah Lutron Light Meter LX-101 AS, seperti pada gambar 3.2..

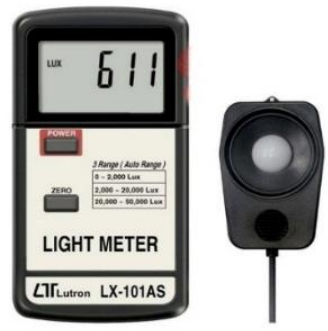

Gbr 3. Alat Ukur Lutron Light Meter LX-101 AS

Spesifikasi teknis alat tersebut ialah: tampilannya menggunakan layar LCD berukuran $44 \mathrm{~mm}$ x $29 \mathrm{~mm}$, sensornya menggunakan filter photo diode, koresi warna dan spectrum sesuai dengan standar Internatonal Commision on Illumination; kemampuan pengukuran pada rentang otomatis dapat dilakukan dengan satuan Lux. Adapun kemampuan pengukuran tersebut termuat dalam tabel 3.

Tbl 3. Spesifikasi Alat Ukur Light Meter LX-101 AS

\begin{tabular}{|c|c|c|c|}
\hline $\begin{array}{c}\text { Rentang } \\
\text { (Lux) }\end{array}$ & $\begin{array}{c}\text { Rentang } \\
\text { yang } \\
\text { ditampilkan } \\
\text { (Lux) }\end{array}$ & $\begin{array}{c}\text { Resolusi } \\
\text { (Lux) }\end{array}$ & Akurasi \\
\hline 2.000 & 0-1.999 & 1 & $\begin{array}{c} \pm(5 \%+4 \\
\text { Lux })\end{array}$ \\
\hline 20.000 & $\begin{array}{l}2.000- \\
19.990\end{array}$ & 10 & $\begin{array}{c} \pm \\
(5 \%+40 \\
\text { Lux })\end{array}$ \\
\hline 50.000 & $\begin{array}{c}20.000- \\
50.000\end{array}$ & 100 & $\begin{array}{c} \pm \\
(5 \%+400 \\
\text { Lux })\end{array}$ \\
\hline
\end{tabular}

\section{b) Hioki Clam On Power HiTester}

Sementara untuk mengetahui besaran listrik, dilakukan pengukuran di lapangan menggunakan peralatan Hioki Clamp On Power HiTester seperti pada gambar 3.3. Berdasarkan data pengukuran ini dapat diketahui nilai parameter kelistrikan seperti tegangan, arus, daya, faktor daya, dan frekuensi. Pengukuran sesaat dilakukan pada panel listrik PJU yang ada.

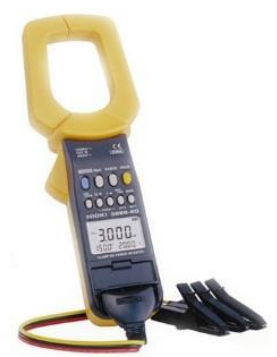

Gbr 4. Hioki Clamp On Power HiTester
Tbl 4. Spesifikasi Hioki Clamp On Power HiTester

\begin{tabular}{lc}
\hline \multicolumn{1}{c}{$\begin{array}{c}\text { Rentang Pengukuran } \\
\text { Tegangan }\end{array}$} & AC 0 - 600V \\
\hline Rentang Pengukuran Arus & AC 1 - 1000 A \\
\hline $\begin{array}{l}\text { Rentang Pengukuran Faktor } \\
\text { Daya }\end{array}$ & $\begin{array}{c}\text { Lead 0 to Lead 1 to } \\
\text { Lead 0 }\end{array}$ \\
\hline Rentang Pengukuran Daya & $0-600 \mathrm{~kW}$ \\
\hline Rentang Pengukuran Energi & $0-9999 \mathrm{kWh}$ \\
\hline Suhu & $0 \mathrm{C}-4^{0} \mathrm{C}$ \\
\hline Kelembaban & $80 \% \mathrm{RH}$ \\
\hline Kelas Meter & Error $2,0 \%$ \\
\hline
\end{tabular}

\section{E. Waktu dan Tempat Penelitian}

a) Waktu penelitian

Penelitian ini dilakukan di Jalan Tol Kabupaten Pangandaran. Pengukuran kuat pencahayaan (iluminasi) dilakukan pada malam hari yaitu pukul 21.00 WIB sampai dengan selesai pada bulan November 2019.

\section{b) Tempat penelitian}

Penelitian ini dilakukan pada bulan November 2019 sampai dengan selesai di Jalan Tol Pangandaran, yang berada di Desa Pananjung, Kecamatan Pangandaran, Kabupaten Pangandaran, Provinsi Jawa Barat.

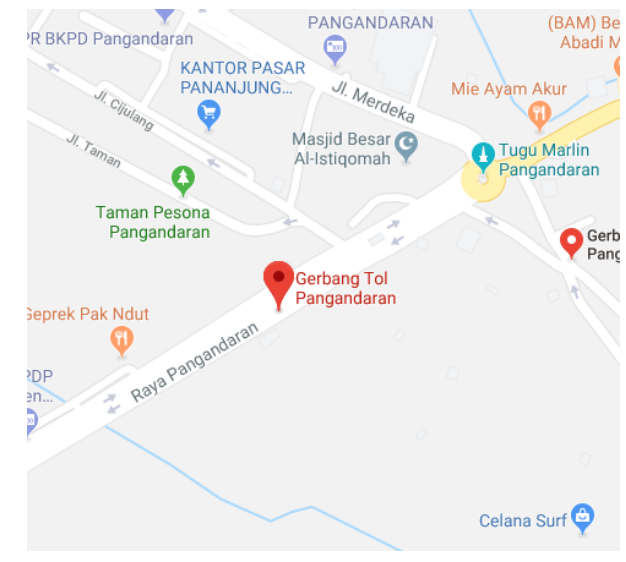

Gbr 5. Peta jalan Tol Kabupaten Pangandaran Sumber: Google maps

\section{HASIL DAN PEMBAHASAN}

\section{A. Metode Pengukuran}

Pengukuran terhadap intensitas cahaya pada Penerangan Jalan Umum (PJU) di Jalan Tol Kabupaten Pangandaran dilakukan pada sembilan titik antara dua titik tiang PJU. Pengukuran ini bertujuan untuk mengetahui tingkat sebaran intensitas cahaya yang dihasilkan. Pengukuran dilakukan pada dua titik tiang PJU dengan lampu yang masih menyala dengan baik.

Pengukuran dilakukan pada malam hari, Pukul 21.00 WIB sampai dengan selesai dengan 10 kali pengukuran. Dengan menggunakan lux meter 


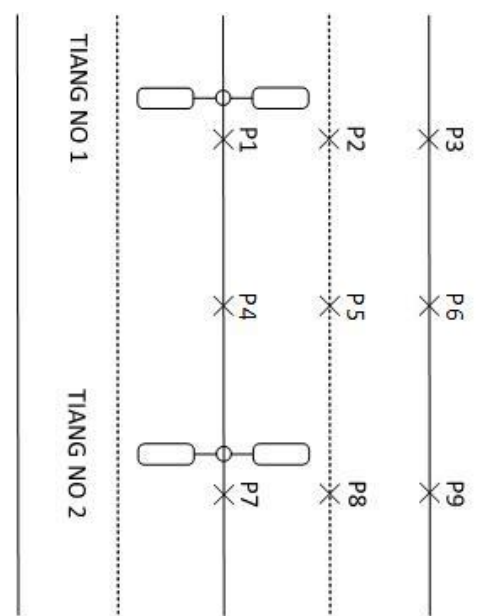

Gbr 6. Metode Sembilan Titik Pengukuran Intensitas Cahaya Lampu Jalan

B. Hasil Pengukuran

Pengukuran terhadap kuat pencahayaan (iluminasi) pada Penerangan Jalan Umum (PJU) di Jalan Tol Kabupaten Pangandaran dilakukan pada sembilan titik antara dua titik tiang PJU. Pengukuran ini bertujuan untuk mengetahui tingkat sebaran intensitas cahaya yang dihasilkan.
Pengukuran dilakukan pada dua titik tiang PJU dengan lampu yang masih menyala dengan baik.

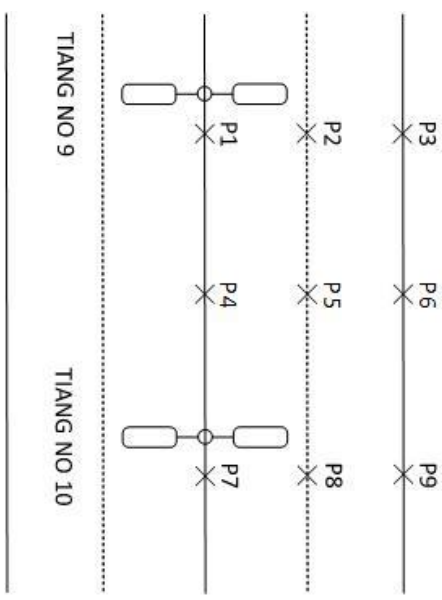

Gbr 7. Eksisting Tiang PJU no 9 dan no 10

Pengukuran terhadap kuat pencahayaan (iluminasi) dilakukan pada satu ruas jalan masing-masing dua tiang PJU yang masih berfungsi dengan baik. Pengukuran dilakukan pada malam hari, Pukul 21.00 WIB sampai dengan selesai dengan 10 kali pengukuran. Hasil pengukuran kuat pencahayaan menggunakan lux meter disajikan pada tabel 4.9

Tbl 5. Pengukuran Lux Meter pada tiang PJU no 9 dan 10 pada sisi jalan sebelah kanan dan simulasi dengan sofware Dialux 4.13

\begin{tabular}{|c|c|c|c|c|c|c|c|c|c|c|c|}
\hline \multirow[t]{2}{*}{ No } & \multirow{2}{*}{\multicolumn{3}{|c|}{$\begin{array}{l}\text { Lampu PJU } \\
\text { sebelah kanan }\end{array}$}} & \multirow{2}{*}{\multicolumn{3}{|c|}{$\begin{array}{c}\text { Lampu LED 150 } \\
\text { Watt Simulasi } \\
\text { dengan sofware } \\
\text { Dialux } 4.13\end{array}$}} & \multirow{2}{*}{\multicolumn{3}{|c|}{$\begin{array}{c}\text { Lampu LED } 120 \\
\text { Watt Simulasi } \\
\text { dengan sofware } \\
\text { Dialux } 4.13\end{array}$}} & \multicolumn{2}{|c|}{$\begin{array}{c}\text { SNI } \\
\text { 7391:2008 }\end{array}$} \\
\hline & & & & & & & & & & \multirow{2}{*}{$\begin{array}{l}\text { Iluminasi } \\
\text { rata-rata } \\
\text { (lux) }\end{array}$} & $\begin{array}{c}\text { Kemerataa } \\
\mathrm{n}(\mathrm{g} 1)\end{array}$ \\
\hline 9. & P1 & $\mathrm{P} 2$ & P3 & P1 & P2 & P3 & P1 & P2 & P3 & & 0.14 Lux - \\
\hline & 3,3 & 6,4 & 1,7 & 35 & 28 & 5.89 & 30 & 23 & 18 & \multirow{8}{*}{$\begin{array}{l}11 \text { Lux - } \\
20 \text { Lux }\end{array}$} & 0.20 Lux \\
\hline & Lux & Lux & Lux & Lux & Lux & Lux & Lux & Lux & Lux & & \\
\hline & P4 & P5 & P6 & P4 & P5 & P6 & P4 & P5 & P6 & & \\
\hline & 0 & 0 & 0 & 4.43 & 4.36 & 3.68 & 3.46 & 4.14 & 4.39 & & \\
\hline & Lux & Lux & Lux & Lux & Lux & Lux & Lux & Lux & Lux & & \\
\hline \multirow[t]{3}{*}{10.} & P7 & P8 & P9 & P7 & P8 & P9 & P7 & P8 & P9 & & \\
\hline & 5,4 & 8,3 & 2,8 & 35 & 28 & 5.89 & 30 & 23 & 18 & & \\
\hline & Lux & Lux & Lux & Lux & Lux & Lux & Lux & Lux & Lux & & \\
\hline
\end{tabular}


Tbl 6. Hasil perhitungan dari pengukuran kuat pencahayaan tiang no 9 dan 10 dan simulasi menggunakan sofware Dialux 4.13

\begin{tabular}{cccc}
\hline No & Jenis Lampu & $\begin{array}{c}\text { Iluminasi } \\
\text { rata-rata } \\
\text { (lux) }\end{array}$ & $\begin{array}{c}\text { Kemerataan } \\
\text { (g1) }\end{array}$ \\
\hline $\mathbf{1}$ & $\begin{array}{c}\text { Lampu Son T 150 W } \\
\text { PJU sebelah kanan }\end{array}$ & 3.1 Lux & 0.00 lux \\
\hline $\mathbf{2}$ & Lampu LED 150 W & 11 Lux & 0.106 Lux \\
& simulasi dengan Dialux & & \\
& 4.13 & & \\
\hline $\mathbf{3}$ & Lampu LED 120 W & 11 Lux & 0.114 Lux \\
& simulasi dengan Dialux & & \\
\hline $\mathbf{4}$ & 4.13 & & $0.14-0.20$ \\
& Menurut SNI 7391:2008 & 11-20 Lux \\
\hline
\end{tabular}

Dari hasil pengukuran pada tiang PJU sebelah kanan nomer 9 dan 10, kuat pencahayaan terukur di lokasi penelitian yang terlihat pada tabel 4.9 , menunjukkan terdapat daerah yang tidak mendapatkan cahaya dari luminer PJU terpasang. Daerah tersebut adalah titik tengah dari panjang jarak antar tiang PJU yaitu titik pengukuran P4, P5, dan P6 pada sisi kanan jalan. Daerah yang tidak mendapatkan cahaya tersebut berjarak 25 meter dari tiang PJU. Minimnya kuat cahaya terukur pada titik tengah antar tiang akan menyebabkan nilai Emin/Emax menjadi sangat kecil, yaitu 0,00 dan nilai iluminasi rata-rata 3.1 lux sehingga belum sesuai dengan nilai yang tercantum pada Tabel 3.3 SNI:7391:2008.

Sedangkan untuk hasil simulasi dengan menggukan sofware dialux 4.13 dengan menggunakan lampu LED 150 Watt, kuat pencahayaan menunjukan nilai iluminasi rata-rata lux sebesar 11 lux dan nilai kemeretaan Emin/Emaks 0.106 lux sehingga nilai iluminasi rata-rata lux dan kemertaan sudah sesuai standard SNI 7391:2008.

untuk hasil simulasi dengan menggukan sofware dialux 4.13 dengan menggunakan lampu LED 120 Watt, kuat pencahayaan menunjukan nilai iluminasi rata-rata lux sebesar 11 lux dan nilai kemeretaan Emin/Emaks 0.114 lux sehingga nilai iluminasi rata-rata lux dan kemertaan sudah sesuai standard SNI 7391:2008.

\section{Simulasi Pencahayaan menggunakan Dialux 4.13}

Simulasi dilakukan menggunakan perangkat lunak Dialux 4.13. Luminer yang digunakan dalam simulasi ini merupakan luminer yang terdapat dalam database salah satu perusahaan lampu.

\section{1) Simulasi menggunakan lampu LED Philips 150 Watt}

Simulasi dilakukan dengan menggunakan data dari Dinas Perhubungan Kabupaten Pangandaran. Data yang diperoleh untuk melakukan simulasi adalah sebagai berikut:

$\begin{array}{lc}\text { 1 : Lebar Trotoar Jalan } & : 2 \text { meter } \\ \text { 2: Lebar Jalan kanan } & : 7 \text { meter } \\ \text { 3: Lebar Jalan kiri } & : 7 \text { meter } \\ 4 \text { : Lebar Median Jalan } & : 5 \text { meter } \\ 5: \text { Kelas Jalan } & : \text { R3 }\end{array}$

Kondisi tiang PJU terpasang berdasarkan data dari Dinas Perhubungan Kabupaten Pangandaran adalah sebagai berikut:

1: Penataan Tiang PJU : 1 Tiang dengan 2 Lampu pada median jalan

2: Jarak antar Tiang PJU : 50 meter

3: Tinggi Tiang : 7 meter

4: Overhang $\quad: 0.500$ meter

5 : Sudut Boom

$: 30^{\circ}$

6 : Panjang Boom : 2 meter

Untuk data luminer yang akan digunakan pada simulasi ini adalah sebagai berikut:

1 : Model Lampu : Philips BGP323 T35

2 : Fluks Luminus (Luminer) : $17056 \mathrm{~lm}$

3 : Fluks Luminus (Lampu) : $20800 \mathrm{~lm}$

4 : Daya $\quad: 150 \mathrm{~W}$

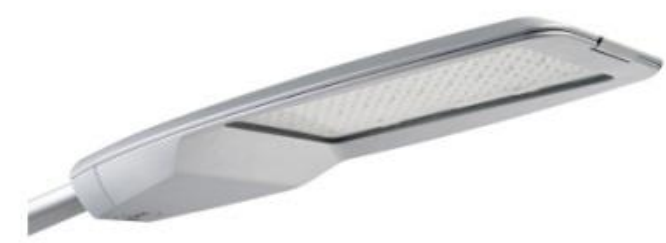

Gbr 8. Lampu Philips LED $150 \mathrm{~W}$

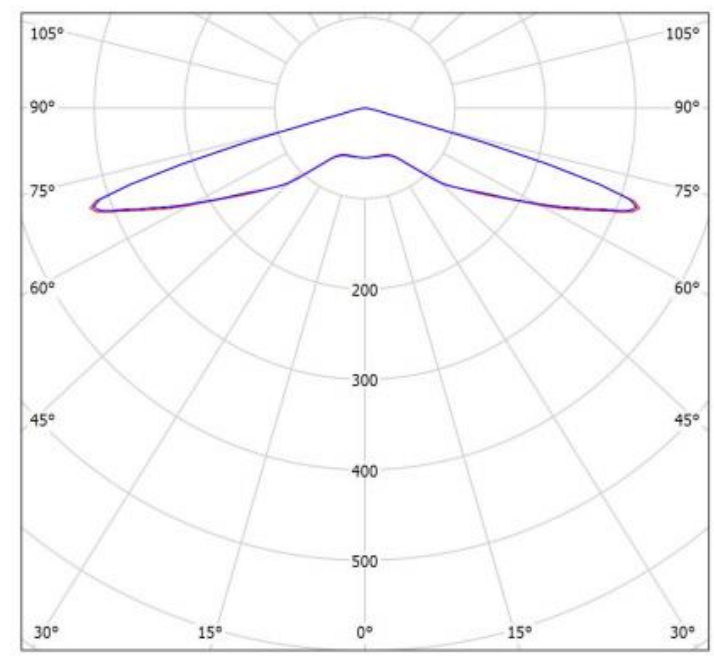

Gbr 9. Fotometri luminer untuk model lampu Philips LED $150 \mathrm{~W}$ 


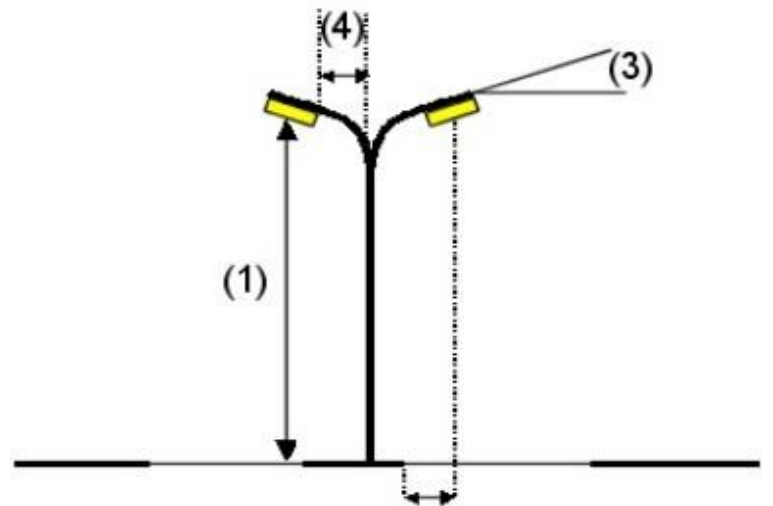

(2)

Gbr 10. Spesifikasi Bentuk Umum Tiang PJU Dengan Dua Luminer Terpasang

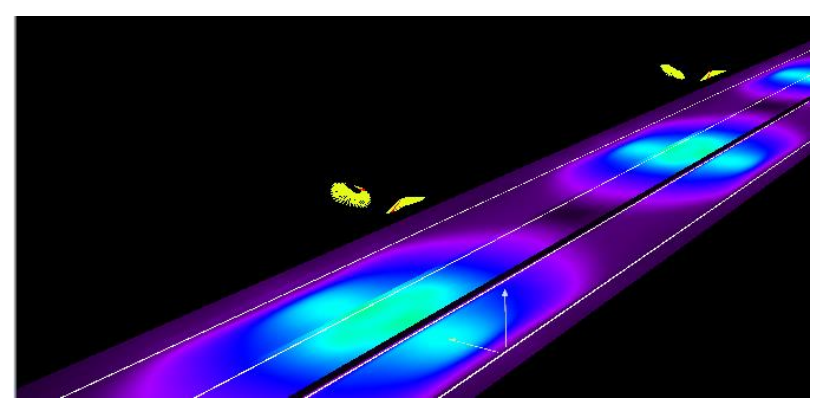

Gbr 11. Hasil Simulasi Penyebaran Kuat

Pencahayaan Eksisting Lampu Philips LED $150 \mathrm{~W}$

Simulasi dilakukan dengan menggunakan sofware Dialux 4.13. Hasil simulasi menunjukkan nilai iluminasi rata-rata 11 lux dan nilai kemerataan cahaya sebesar 0,106 lux sehingga nilai iluminasi rata-rata lux dan kemertaan sudah sesuai standard SNI 7391:2008.

Tbl 7. Nilai sebaran lux pada saat simulasi

Street 1 / Valuation Field Roadway 2 / Table (E)

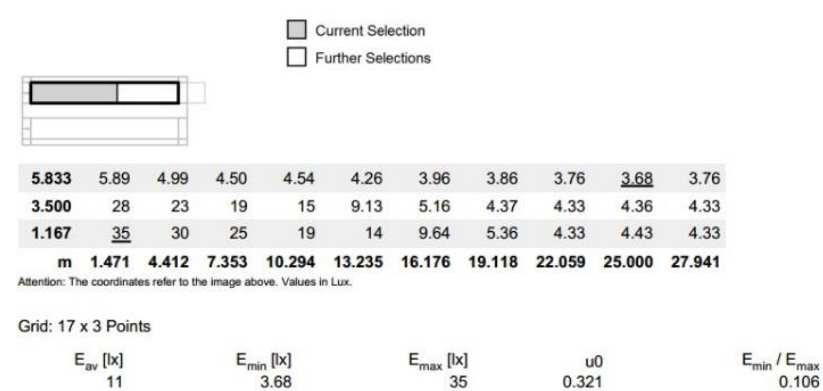

Street 1 / Valuation Field Roadway 2 / Table (E)

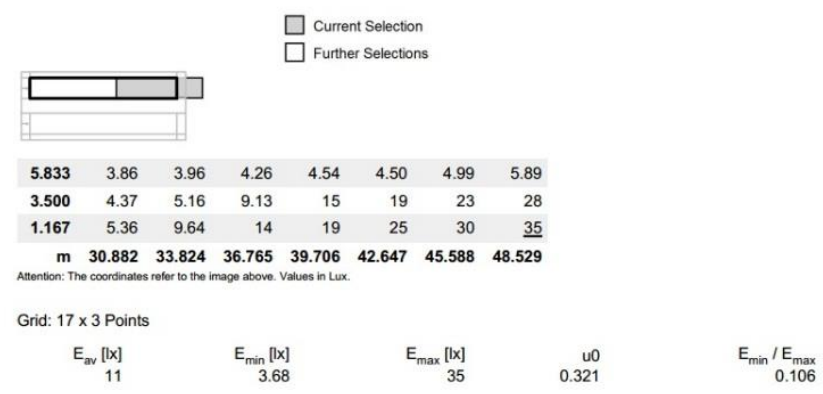

Simulasi dilakukan dengan menggunakan sofware Dialux 4.13. Hasil simulasi menunjukkan nilai kuat pencahyaan sebagai berikut :

$\begin{array}{ll}\mathrm{E} \max & : 35 \operatorname{lux} \\ \mathrm{E} \min & : 3.68 \mathrm{lux} \\ \mathrm{E} \text { av } & : 11 \text { lux } \\ \mathrm{E} \min / \max & : 0.106 \mathrm{lux} \\ \mathrm{u} 0 & : 0.321\end{array}$

Nilai iluminasi rata-rata 11 lux dan nilai kemerataan 0.106 lux sehingga nilai iluminasi rata-rata lux dan kemertaan sudah sesuai standard SNI 7391:2008.

2) Simulasi menggunakan lampu LED Philips 120 Watt

Simulasi dilakukan dengan menggunakan data dari Dinas Perhubungan Kabupaten Pangandaran. Data yang diperoleh untuk melakukan simulasi adalah sebagai berikut:

$1:$ Lebar Trotoar Jalan $: 2$ meter

2: Lebar Jalan kanan :7 meter

3: Lebar Jalan kiri : 7 meter

4 : Lebar Median Jalan : 5 meter

$5:$ Kelas Jalan : R3

Kondisi tiang PJU terpasang berdasarkan data dari Dinas Perhubungan Kabupaten Pangandaran adalah sebagai berikut:

1: Penataan Tiang PJU : 1 Tiang dengan 2 Lampu pada median jalan

2: Jarak antar Tiang PJU : 50 meter

3: Tinggi Tiang : 7 meter

4: Overhang $: 0.500$ meter

5 : Sudut Boom : $0.5^{\circ}$

6 : Panjang Boom : 2 meter

Untuk data luminer yang akan digunakan pada simulasi ini adalah sebagai berikut:

1 : Model Lampu

: Philips BGP353 T25

2 : Fluks Luminus (Luminer) : $10492 \mathrm{~lm}$

3 : Fluks Luminus (Lampu) : $12200 \mathrm{~lm}$

4 : Daya $\quad: 150 \mathrm{~W}$ 




Gbr 9. Fotometri luminer untuk model lampu Philips LED $120 \mathrm{~W}$

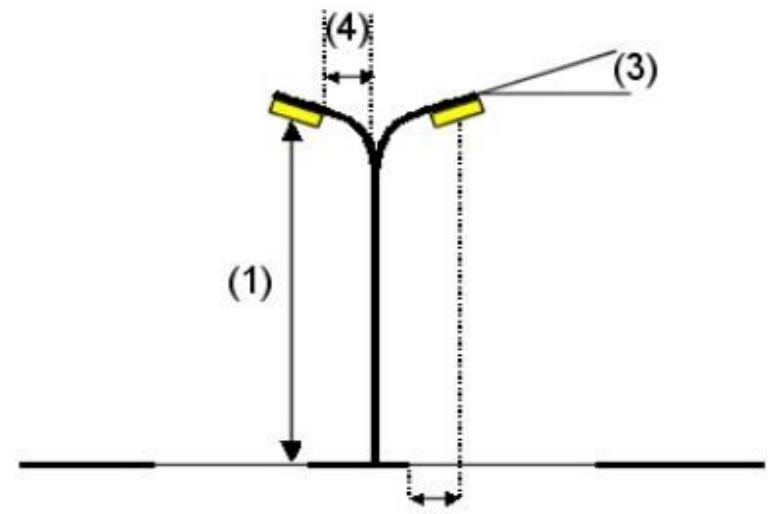

(2)

Gbr 10. Spesifikasi Bentuk Umum Tiang PJU Dengan Dua Luminer Terpasang



Gbr 11. Hasil Simulasi Penyebaran Kuat Pencahayaan Eksisting Lampu Philips LED $120 \mathrm{~W}$

Simulasi dilakukan dengan menggunakan sofware Dialux 4.13. Hasil simulasi menunjukkan nilai iluminasi rata-rata 11 lux dan nilai kemerataan cahaya sebesar 0,114 lux sehingga nilai iluminasi rata-rata lux dan kemertaan sudah sesuai standard SNI 7391:2008.
Tbl 7. Nilai sebaran lux pada saat simulasi Street 1 / Valuation Field Roadway 2 / Table (E)



Simulasi dilakukan dengan menggunakan sofware Dialux 4.13. Hasil simulasi menunjukkan nilai kuat pencahyaan sebagai berikut :

$\begin{array}{ll}\text { E max } & : 30 \text { lux } \\ \text { E min } & : 3.16 \text { lux } \\ \text { E av } & : 11 \text { lux } \\ \text { E min/max } & : 0.114 \text { lux } \\ \text { u0 } & : 0.316\end{array}$

Nilai iluminasi rata-rata 11 lux dan nilai kemerataan 0.114 lux sehingga nilai iluminasi rata-rata lux dan kemertaan sudah sesuai standard SNI 7391:2008.

D. Kondisi Besaran Listrik

Pengukuran besaran listrik dilakukan pada panel listrik untuk distribusi PJU Jalan Tol Kabupaten Pangandaran. Pengukuran dilakukan dengan menyalakan seluruh luminer yang masih berfungsi. Pengukuran dilakukan pada panel listrik yang melayani 6 titik luminer PJU yang masih berfungsi. Hasil pengukuran disajikan pada tabel 4.39.

Tb1 9. Data pengukuran besaran listrik

\begin{tabular}{cccc}
\hline $\begin{array}{c}\text { Tegangan } \\
(\mathbf{V})\end{array}$ & Arus (A) & $\begin{array}{c}\text { Faktor Daya } \\
(\cos \phi)\end{array}$ & $\begin{array}{c}\text { Daya } \\
\text { Nyata } \\
(\mathbf{k W})\end{array}$ \\
\hline $\mathbf{2 2 6}$ & 11 & 0.44 & 1.1 \\
\hline
\end{tabular}

\section{1) Konsumsi Daya PJU Eksisting}

Untuk lampu PJU $150 \mathrm{~W}$ dijalan Tol Kabupaten Pangandaran berjumlah 36 unit, maka energi yang terpakai pada PJU ini dapat dihitung sebagai berikut:

Ptotal $=P \times N$

$$
=150 \times 36
$$




\section{$=5.400 \mathrm{Watt}$}

Jika dalam sebulan diperkirakan pemakaian sebanyak 360 jam, maka total jumlah konsumsi daya nyata sebagai berikut:

Pbulan $=$ Ptotal $x t$

$=5.400 \times 360$

$=1.944 \mathrm{kWh} / \mathrm{bulan}$

\section{2) Konsumsi Daya PJU LED 150 Watt}

Untuk lampu LED $150 \mathrm{~W}$ dijalan Tol Kabupaten Pangandaran berjumlah 36 unit, maka energi yang terpakai pada PJU ini dapat dihitung sebagai berikut:

Ptotal $=P \times N$

$$
\begin{aligned}
& =150 \times 36 \\
& =5.400 \mathrm{Watt}
\end{aligned}
$$

Jika dalam sebulan diperkirakan pemakaian sebanyak 360 jam, maka total jumlah konsumsi daya nyata sebagai berikut:

Pbulan $=$ Ptotal $x t$

$$
\begin{aligned}
& =5.400 \times 360 \\
& =1.944 \mathrm{kWh} / \text { bulan }
\end{aligned}
$$

\section{3) Konsumsi Daya PJU LED 120 Watt}

Untuk lampu LED $120 \mathrm{~W}$ dijalan Tol Kabupaten Pangandaran berjumlah 36 unit, maka energi yang terpakai pada PJU ini dapat dihitung sebagai berikut:

Ptotal $=P \times N$

$$
\begin{aligned}
& =120 \times 36 \\
& =4.320 \mathrm{Watt}
\end{aligned}
$$

Jika dalam sebulan diperkirakan pemakaian sebanyak 360 jam, maka total jumlah konsumsi daya nyata sebagai berikut:

Pbulan $=$ Ptotal $x t$

$$
\begin{aligned}
& =4.320 \times 360 \\
& =1.555 \mathrm{kWh} / \text { bulan }
\end{aligned}
$$

\section{F. Resume PJU Eksisting dan PJU LED}

Setelah dilakukan perhitungan dan simulasi pada lampu Son T $150 \mathrm{~W}$,lampu Led Philips $150 \mathrm{~W}$ dan $120 \mathrm{~W}$ maka dapat diketahui berapa nilai yang dihasilkan dari masing-masing lampu seperti yang tercantum pada tabel 4.40 .

Tbl 10. Resume Pemakaian Luminer PJU Eksisting dan PJU LED

\begin{tabular}{lccc}
\hline \multicolumn{1}{c}{ Parameter } & $\begin{array}{c}\text { Lampu } \\
\text { PJU } \\
\text { Eksisting }\end{array}$ & $\begin{array}{c}\text { Lampu } \\
\text { LED 150 }\end{array}$ & $\begin{array}{c}\text { Lampu } \\
\text { LED 120 } \\
\text { W }\end{array}$ \\
\hline Daya (W) & 150 & 150 & 120 \\
\hline Daya Semu (VA) & 340.9 & 157.8 & 126.3 \\
\hline Luminous (lumen) & 15000 & 17800 & 11834 \\
\hline E min (Lux) & 0.0 & 3.68 & 3.46 \\
\hline E max (Lux) & 8.3 & 35 & 30 \\
\hline Eavg (Lux) & 3.1 & 11 & 11 \\
\hline Emin/Emax & 0.0 & 0.106 & 0.114 \\
\hline Tiang (Buah) & 18 & 18 & 18 \\
\hline $\begin{array}{l}\text { Jumlah luminer } \\
\text { (Unit) }\end{array}$ & 36 & 36 & 36 \\
\hline $\begin{array}{l}\text { Jarak antar tiang } \\
\text { (Meter) }\end{array}$ & 50 & 50 & 50 \\
\hline
\end{tabular}

\begin{tabular}{lccc}
\hline $\begin{array}{l}\text { Energi Listrik } \\
\text { (kWh/perbulan) }\end{array}$ & 1.944 & 1.944 & 1.555 \\
\hline $\begin{array}{l}\text { Suplai Tenaga } \\
\text { Listrik (VA) }\end{array}$ & 12.272 & 5.680 & 4.546 \\
\hline
\end{tabular}

\section{KESIMPULAN}

Dari hasil penelitian tentang Analisis Pencahayaam Penerangan Jalan Umum dijalan Tol Kabupaten Pangandaran dan Peluang Hemat Energi dapat ditarik kesimpulan sebagai berikut:

1. Kondisi PJU eksisting di ruas Jalan Tol Kabupaten Pangandaran tingkat iluminasi rata-rata yang dihasilkan dari lampu SON-T 150W sebesar 3,1 lux dengan kemerataan cahaya sebesar 0,0. Jika mellihat ketentuan SNI 7391:2008 maka belum sesuai SNI. Sedangkan hasil simulasi yang telah dilakukan dengan sofware dialux 4.13, tingkat iluminasi rata-rata yang dihasilkan dari luminer Philips LED $150 \mathrm{~W}$ sebesar 11 lux dengan kemerataan cahaya sebesar 0.106 lux. Jika mellihat ketentuan SNI 7391:2008 maka tingkat iluminasi ratarata dan nilai kemerataan sudah sesuai SNI 7391:2008. Untuk hasil simulasi dari luminer Philips LED $120 \mathrm{~W}$ tingkat iluminasi rata-rata sebesar 11 lux dengan kemerataan cahaya sebesar 0.114 lux. Jika mellihat ketentuan SNI 7391:2008 maka tingkat iluminasi ratarata dan nilai kemerataan sudah sesuai SNI 7391:2008.

2. Dari hasil simulasi yang telah dilakukan dengan sofware Dialux 4.13, penggunaan lampu LED $120 \mathrm{~W}$ pada Penerangan Jalan Umum dijalan Tol Kabupaten Pangandaran menghasilkan peluang penghematan energi listrik sebesar $20 \%$

\section{DAFTAR PUSTAKA}

[1] W. S. Hadi, D. Notosudjono, and D. B. Fiddiansyah, "Perencanaan Sistem Penerangan Jalan Umum Photovoltaik Di Taman Wisata Matahari," Jom Unpak, vol. 1, pp. 1-12, 2018.

[2] D. E. B. T. dan K. E. K. ESDM, EFISIENSI ENERGI PENCAHAYAAN JALAN UMUM BUKU II:PERENCANAAN SISTEM PJU EFISIEN ENERGI. 2012.

[3] D. K. Pangandaran, "Selayang Pandang Kabupaten Pangandaran," 2013. [Online]. Available: https://portal.pangandarankab.go.id/tentangpangandaran.

[4] S. Oktamia, "Analisa pemasangan penerangan jalan umum di kota klaten," vol. 1, pp. 1-18, 2018.

[5] S. N. Fahmi, "Analisis dan perencanaan pju sepanjang pesisir pantai barat pangandaran dengan menggunakan dialux evo tugas akhir," 2020.

[6] DIRJEND Bina Marga and D. P. J. Kota, "Lampu Penerangan Jalan Perkotaan Direktorat Jenderal Bina Marga," no. 12, 1991.

[7] Badan Standarisasi Nasional, "Spesifikasi penerangan jalan di kawasan perkotaan (Standar Nasional Indonesia 7391 :2008)," pp. 1-52, 2008.

[8] T. U. Syamsuri, "Kontrol Lampu Jalan untuk Menghemat Energi,” vol. 7, pp. 28-33, 2015. 
[9] M. Mustaqim and M. Haddin, "Perhitungan Kuat Cahaya Pada Penerangan Jalan Umum Berstandar SNI 7391:2008," Setrum Sist. Kendali-TenagaElektronika-Telekomunikasi-Komputer, vol. 6, no. 1, p. 106, 2017. 